\title{
O. Lipschits, Y. Gadot, D. Langgut. The Riddle of Ramat Rahel: The Archaeology of a Royal Persian Period Edifice
}

\section{Astrid Nunn}

\section{(2) OpenEdition Journals}

Édition électronique

URL : http://journals.openedition.org/abstractairanica/41602

DOI : 10.4000/abstractairanica.41602

ISSN : 1961-960X

Éditeur :

CNRS (UMR 7528 Mondes iraniens et indiens), Éditions de l'IFRI

\section{Référence électronique}

Astrid Nunn, « O. Lipschits, Y. Gadot, D. Langgut. The Riddle of Ramat Rahel: The Archaeology of a Royal Persian Period Edifice », Abstracta Iranica [En ligne], Volume 34-35-36 | 2017, document 50, mis en ligne le 15 juillet 2016, consulté le 30 septembre 2020. URL : http://journals.openedition.org/ abstractairanica/41602 ; DOI : https://doi.org/10.4000/abstractairanica.41602

Ce document a été généré automatiquement le 30 septembre 2020.

Tous droits réservés 


\title{
O. Lipschits, Y. Gadot, D. Langgut. The Riddle of Ramat Rahel: The Archaeology of a Royal Persian Period Edifice
}

\author{
Astrid Nunn
}

\section{RÉFÉRENCE}

O. Lipschits, Y. Gadot, D. Langgut. « The Riddle of Ramat Rahel: The Archaeology of a Royal Persian Period Edifice ». Trans., 41, 2012, p. 57-79.

1 Le complexe palatial fouillé à Ramat Raḥel au niveau Va a été daté au Fer II, alors que les centaines d'estampilles YHWD sont achéménides. Même si celles-ci ont été découvertes dans un contexte architectural peu clair, elles devraient être l'indice d'une importante architecture administrative achéménide qui manque par ailleurs. Les AA. ont essayé de résoudre cette dichotomie. Ramat Rahel a été fouillé dans les années 1930, 1950 et 1960. Le renouveau de la recherche sur ce site et la préparation de la publication finale ont amené les AA. à réévaluer l'architecture « du Fer » et à la redater. Le niveau IVb, d'abord placé à l'époque perse-hellénistique mais dont l'architecture est trop pauvre pour expliquer les estampilles, est maintenant hellénistique. Le niveau Va de l'imposant complexe palatial est par contre daté à la fin du Fer II et à l'époque achéménide. Ce palais de 50×100 m (il manque l'échelle sur le plan !) au plan régulier, muni de deux grandes cours et bordé d'un jardin à l'ouest, a été achevé en trois phases de construction. En redatant ce bâtiment, les AA. arrivent ainsi à la conclusion que, au vu de la belle architecture, les estampilles et la céramique, Ramat Rahel était un centre administratif impérial et la résidence d'un gouverneur perse. 


\section{AUTEURS}

\section{ASTRID NUNN}

Université de Munich 